\title{
Barriers and Facilitators to Older Adults Participating in Fall-Prevention Strategies After Transitioning Home from Acute Hospitalization: A Scoping Review
}

This article was published in the following Dove Press journal:

Clinical Interventions in Aging

\author{
Huey-Ming Tzeng (D) \\ Udoka Okpalauwaekwe (iD ${ }^{2}$ \\ Elizabeth J Lyons $\mathbb{1 D}^{3}$
}

'The University of Texas Medical Branch, School of Nursing, Galveston, TX, USA; ${ }^{2}$ University of Saskatchewan, College of Medicine, Saskatoon, Saskatchewan S7N 2Z4, Canada; ${ }^{3}$ University of Texas Medical Branch, Department of Nutrition and Metabolism, School of Health Professions, Galveston, TX, USA
Correspondence: Huey-Ming Tzeng The University of Texas Medical Branch at Galveston, School of Nursing, 30 University Boulevard, Galveston, TX 77555, USA

Tel + I-734-358-0358

Email tzenghm@gmail.com
Purpose: Approximately, 14\% of older adults aged 65 years and over experience a fall within 1 month post-hospital discharge. Adequate self-management may minimize the impact of these falls; however, research is lacking on why some older adults engage in self-management to prevent falls while others do not.

Methods: We conducted a scoping review to identify barriers and facilitators to older adults participating in fall-prevention strategies after transitioning home from acute hospitalization. Eligibility criteria were peer-reviewed journal articles published during 2009-2019 which were written in English and contained any of the following keywords or their synonyms: "fall-prevention," "older adults," "post-discharge" and "transition care." We systematically and selectively summarized the findings of these articles using the Joanna Briggs Institute guidelines and the PRISMA-ScR reporting guidelines. Seven bibliographic databases were searched: PubMed/MEDLINE, ERIC, CINAHL, Cochrane Library, Scopus, PsycINFO, and Web of Science. We used the Capability-Opportunity-Motivation-Behavior (COM-B) model of health behavior change as a framework to guide the content, thematic analysis, and descriptive results.

Results: Seventeen articles were finally selected. The most frequently mentioned barriers and facilitators for each COM-B dimension differed. Motivation factors include such as older adults lacking inner drive and self-denial of being at risk for falls (barriers) and following-up with older adults and correcting inaccurate perceptions of falls and fall-prevention strategies (facilitators).

Conclusion: This scoping review revealed gaps and future research areas in fall prevention relative to behavioral changes. These findings may enable tailoring feasible fall-prevention interventions for older adults after transitioning home from acute hospitalization.

Keywords: falls, falls with injury, older adults, post-discharge care, transition care, patientcentered care

\section{Introduction}

In late 2019, the US Centers for Medicare \& Medicaid Services ${ }^{1}$ announced a rule related to the Medicare Post-Acute Care Transformation Act that post-acute rehabilitation service sectors must empower and engage patients to actively participate in their discharge planning. This rule is intended to reduce patients' chances of rehospitalization after transitioning home from the hospital or other post-acute rehabilitation services. ${ }^{1}$ Post-hospital fall-related injuries are a leading diagnosis upon readmission among Medicare patients, particularly for those originally admitted with fall-related injuries or cognitive impairment. ${ }^{2}$ Approximately $14 \%$ 
of older adults aged 65 and over have experienced a fall within 1 month post-hospital discharge, ${ }^{3}$ and $40 \%$ of older adults have fallen within 6 months after discharge. ${ }^{3-5}$ Older adults may require additional assistance to remain independent in their homes as they age and remain fallfree within the first month post-hospital discharge. ${ }^{6}$

Many factors cause falls, including impaired cognition, mobility, gait, and balance; a history of falling; and dependence in daily living activities. ${ }^{7}$ In 2009 , in the US, $31.7 \%$ of adults aged $\geq 65$ years, who experienced a fall, had a fall-related injury. ${ }^{8}$ Of the approximately 52 million older adults in the US (5.7\%), over 3 million are treated in emergency departments for fall-related injuries annually, and over 800,000 of them are hospitalized. Over half of all post-hospital fall-related injuries lead to other injuries (eg, a fractured hip), functional decline, ${ }^{4}$ or rehospitalization ${ }^{4,5}$ with substantial health-care costs. ${ }^{3}$ Recent studies have shown that adequate selfmanagement may minimize the impact of falls in older adults. ${ }^{9-16}$ However, research is lacking on why some older adults engage in self-management actions and behaviors to prevent falls while others do not. ${ }^{15}$ Research is needed to explore possible barriers and facilitators to engaging older patients in preventing falls post-hospitalization. ${ }^{17-19}$

\section{Study Rationale}

Hospitals urgently need to assist with post-hospital transitional efforts to prevent falls to address the burden and costs of these falls. ${ }^{2}$ Randomized controlled trials (RCTs) involving multifactorial patient-centered fall-prevention interventions in acute care settings have demonstrated reduced fall rates by tailoring patient education and care plans based on patients' fall risks. ${ }^{20-23}$ Clinical practice guidelines recommend multifactorial interventions that assess individual risk factors, followed by specific interventions targeting those risk factors to prevent older adults from falling. . $^{15,24}$

Because of the increasing number of older adults at risk, the physical and psychological impact associated with falls, and the high associated health-care costs, additional research is warranted to design and test age-related and culturally sensitive interventions for older adults posthospitalization. ${ }^{2,25,26}$

\section{Study Objectives}

This scoping review aimed to identify barriers and facilitators to older adults participating in fall-prevention activities after transitioning home from acute hospitalization. The short-term goal of this research was to use the results of the synthesized review to design patient-centered fall-prevention strategies for older adults transitioning home after hospitalization. We intend to use the framework for the study of complex mHealth interventions in diverse cultural settings by Maar et $\mathrm{al}^{27}$ to develop fallprevention interventions, emphasizing process evaluation to engage potential users (ie, older adults) and other stakeholders (ie, caregivers, health-care providers, and policymakers). The results may ignite future research to codevelop interventions that older adults can easily adopt to prevent falls, for example, by identifying major active components, incorporating technology to facilitate adoption, ensuring cultural congruence, and understanding the unintended consequences. ${ }^{27}$

\section{Materials and Methods}

We conducted a scoping review and systematically and selectively summarized the research findings of the identified articles. We used the Joanna Briggs Institute (JBI) guideline to guide the methodology, ${ }^{28}$ which was based on an earlier methodological framework by Arksey and O'Malley. ${ }^{29}$ We used the Preferred Reporting Items for Systematic reviews and Meta-Analyses extension for Scoping Reviews (PRISMA-ScR) as our reporting guideline. ${ }^{30}$ As a scoping review manuscript, the study presented in this paper does not require Institutional Review Board/Ethics Committee oversight.

\section{Protocol and Registration}

This study had no pre-published or registered protocol before its commencement.

\section{Eligibility Criteria}

The eligibility criteria included peer-reviewed journal articles in all designs that were published between 2009 and 2019, were written in English, and assessed a combination of any of the following keywords or their synonyms: "fallprevention," "older adults," "post-discharge" and "transition care." We formed the idea of this study in mid-2019 and set the review start date as 2009. Since we included articles in all designs, including systematic review articles, we considered the review period from 2009 to 2019 as being current and practical to conduct a thorough scoping review. 


\section{Information Sources}

We consulted with a librarian to assist in defining the keywords and combinations. We searched seven electronic bibliographic databases (PubMed/MEDLINE, ERIC, CINAHL, Cochrane Library, Scopus, PsycINFO, and Web of Science) and used a syntax composed of all identified keywords and their synonyms.

\section{Search Strategy}

We conducted the initial search between September 2, 2019, and September 15, 2019, and an updated search on February 5,2020 . We also hand-searched the references of the included articles and applied the "snowball phenomenon" to identify relevant peer-reviewed articles in the methodological framework. Gray literature searches were excluded from our search strategy. Box 1 lists the search syntax used in the library search for relevant journal articles.

\section{Selection of Evidence Sources}

We employed two iterative stages to identify articles. In the first stage, we screened the article titles and abstracts after collating the articles and removing duplicates. We then evaluated these articles by carefully reading the full text. In the second stage, two authors (HMT and UO) independently screened and reviewed all full-text articles and assigned a score of either 0 or $1(0=$ not relevant; $1=$ relevant) to each article. The overall reviewer reliability score (kappa score) was calculated, and any disagreements were resolved by consensus. The overall kappa score was

Box I Keyword Search Syntax and Search Strategy for the PubMed/MEDLINE, ERIC, CINAHL, Cochrane Library, Scopus, PsycINFO, and Web of Science Databases

I. Fall prevention/
2. (fall adjl prevention).ti.ab
3. (fall adjl (control or reduction or prevention)) adj2 strateg\$.ti.ab
4. (fall adjl (control or reduction or prevention)) adj2 program $\$ . t i . a b$
5. \#2 AND \#3 AND \#4
6. Older adult $\$$ I
7. Older adjl adult $\$$ or seniors $\$$ or the adj2 elderly or the adj2 aged
or geriatr $\$ . t i . a b$
8. Post dischargel
9. Post adj3 discharge or post adj3 hospital adj3 discharge or after
adj3 discharge or after adj3 hospital discharge or transition $\$$ adj3
care.ti.ab
I0. \#5 AND \#7
II. \#9 AND \#I0

0.837 (standard error $=0.062 ; \mathrm{p}<0.0001$ ). All citations were imported or manually entered using the reference manager, Endnote X9. ${ }^{31}$

\section{Data Charting and Items}

We extracted data from the final selected articles based on preidentified data items: author(s), title and date of publication, study type and design, materials and methodology, data collection methods, stage of the care continuum on which the study focused, setting, barriers or facilitators, limitations, and lessons learned. For each selected study, the authors (HMT and UO) extracted and coded the data as barriers and facilitators to fall-prevention compliance in intervention studies where fall-prevention strategies recorded the negative and positive impacts, respectively, in decreasing fall occurrences at home post-hospitalization. For example, we abstracted information regarding barriers when the intervention provided limited success in reducing falls post-discharge. All data were compiled into a spreadsheet using Microsoft Excel 2016. ${ }^{32}$

\section{Critical Appraisal of Individual Evidence Sources}

Given the varying study designs and methodologies used in the included studies, we appraised their characteristics and methodological quality. We assessed the methodological quality of each included article using the JBI critical appraisal tools ${ }^{33}$ for qualitative studies, randomized clinical studies, systematic reviews, prospective studies, and cross-sectional studies. We used the methodological quality rating to verify the quality of the studies included in this scoping review. Readers may obtain a copy of the appraisal results from the corresponding author.

\section{Synthesis of Results}

We used the Capability-Opportunity-Motivation-Behavior (COM-B) model of health behavior change $\mathrm{e}^{34,35}$ to guide the content, thematic analysis, and descriptive results of the review synthesis. The COM-B model conceptualizes behavioral change strategies into three groups: capability, opportunity, and motivation. The use of this model could support intervention designs and improve the process of intervention evaluation and theory development. ${ }^{34,35} \mathrm{We}$ characterized the behavior change strategies related to preventing falls when older adults transitioned home after hospitalization. Fall-prevention strategies can address a patient's capability, opportunity, or motivation singly or 
jointly because these three components interact to generate patients' behavioral changes. ${ }^{34,35}$

Two authors (HMT and UO) met ten times via video conference to discuss concerns, resolve conflicts, and review the research protocols to ensure strict adherence. The other author (EL), a behavioral scientist, joined two video conferencing calls and independently reviewed and commented on the results. Several disagreements among the three authors (HMT, UO, EL) were identified (ie, themes, subthemes, and themes being regrouped into either the capability, opportunity, or motivation category). Conflicting themes were resolved by consensus during the conference calls or e-mail communication.

\section{Results}

\section{Selection of Evidence Sources}

We identified 166 articles by searching the library databases $(n=135)$ and by hand-searching/snowballing $(n=31)$. Of these 166 articles, 28 were excluded as duplicates, resulting in 138 articles for screening. One author (UO) independently screened the article abstracts and titles, after which, 62 articles were excluded. Subsequently, the full text of the remaining 76 articles was screened for selection and inclusion based on relevance to the research question.
Finally, 17 articles were included in this study. Studies were excluded during the final screening if they were not written in English, did not report barriers or facilitators to fall-prevention intervention, did not specify falls or fallprevention interventions, did not specify post-discharge or transitional care, or were not journal articles (Figure 1).

All included articles were original studies or systematic reviews related to post-discharge or transitional care and fall prevention among older adults. The authors (HMT and UO) agreed to add two systematic reviews. ${ }^{36,37}$ Although these two systematic review articles ${ }^{36,37}$ did not fully meet the eligibility criteria for studies on post-hospitalization care, the authors (HMT and UO) concluded that both articles $^{36,37}$ provided in-depth information that elucidated fall-prevention strategies and characteristics spanning the care continuum (including post-discharge).

\section{Characteristics of Evidence Sources}

Table 1 summarizes the general and methodological characteristics of the 17 reviewed studies. Ten of the reviewed articles $(58.8 \%)$ were published in 2009-2014, ${ }^{5,38-46}$ and seven (41.2\%) were published in 2015-2019. ${ }^{19,36,37,47-50}$ Six were conducted in Australia, ${ }^{5,19,41-43,45}$ five in the United States, ${ }^{38,39,48-50}$

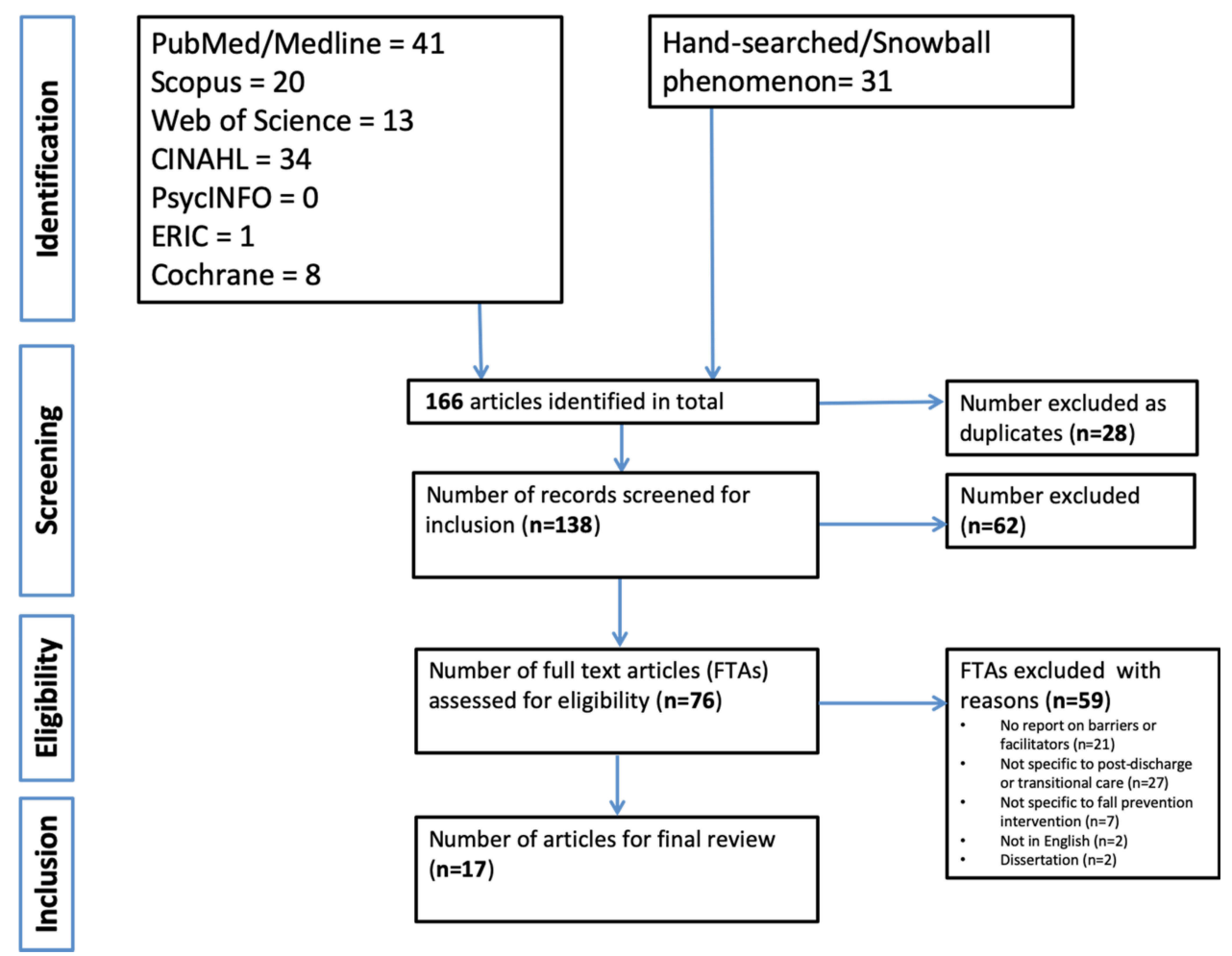

Figure I PRISMA flowchart showing selection of articles for scoping review. 
Table I General and Methodological Characteristics of All Included Articles ( $n=17)$

\begin{tabular}{|c|c|c|}
\hline Publication Year & n (\%) & Article Citations \\
\hline 2009-20I4 & $10(58.8)$ & {$[5,38-46]$} \\
\hline $2015-2019$ & $7(4 I .2)$ & {$[19,36,37,47-50]$} \\
\hline Country/Setting & n (\%) & Article Citations \\
\hline Australia & $6(35.3)$ & {$[5,19,4 \mid-43,45]$} \\
\hline Hong Kong & I (5.9) & {$[46]$} \\
\hline Israel & I (5.9) & {$[47]$} \\
\hline Sweden & I (5.9) & {$[37]$} \\
\hline UK & $3(17.6)$ & {$[36,40,44]$} \\
\hline USA & $5(29.4)$ & {$[38,39,48-50]$} \\
\hline Study Type & n (\%) & Article Citations \\
\hline Quantitative & $5(29.4)$ & {$[5,39,45,47,48]$} \\
\hline Qualitative & $6(35.35)$ & {$[36,38,40,44,49,50]$} \\
\hline Mixed methods & $6(35.3)$ & {$[|9,37,4|-43,46]$} \\
\hline Study Design & n (\%) & Article Citations \\
\hline Case studies & $2(11.8)$ & {$[38,40]$} \\
\hline Cross-sectional & I (5.9) & {$[48]$} \\
\hline $\begin{array}{l}\text { Prospective, excluding } \\
\text { randomized clinical trials }\end{array}$ & $4(23.5)$ & {$[39,46,49,50]$} \\
\hline Randomized clinical trials & $4(23.5)$ & {$[5,41,42,45]$} \\
\hline $\begin{array}{l}\text { Prospective, with a nested } \\
\text { retrospective study }\end{array}$ & I (5.9) & [47] \\
\hline Grounded theory & I (5.9) & [44] \\
\hline Systematic review & $4(23.5)$ & {$[19,36,37,43]$} \\
\hline $\begin{array}{l}\text { Data Collection } \\
\text { Methods }\end{array}$ & n (\%) & Article Citations \\
\hline $\begin{array}{l}\text { Structure/semi-structured } \\
\text { interviews }\end{array}$ & $4(23.5)$ & {$[38,44,49,50]$} \\
\hline Focus group discussions & I (5.9) & {$[40]$} \\
\hline Survey questionnaires & $5(29.4)$ & {$[5,39,45,47,48]$} \\
\hline Mixed methods & $3(17.6)$ & {$[4 I, 42,46]$} \\
\hline $\begin{array}{l}\text { Secondary data (eg, review } \\
\text { studies) }\end{array}$ & $4(23.5)$ & {$[19,36,37,43]$} \\
\hline $\begin{array}{l}\text { Stage in the } \\
\text { Continuum on Which } \\
\text { the Study Focused }\end{array}$ & n (\%) & Article Citations \\
\hline $\begin{array}{l}\text { After acute hospitalization, } \\
\text { but recruited from the } \\
\text { community }\end{array}$ & $3(17.6)$ & {$[38,40,48]$} \\
\hline $\begin{array}{l}\text { Post-hospital discharge for } \\
\text { up to } 8 \text { days }\end{array}$ & I (5.9) & [49] \\
\hline $\begin{array}{l}\text { Post-hospital discharge for } \\
\text { up to I month }\end{array}$ & $5(29.4)$ & {$[5,39,43,47,50]$} \\
\hline $\begin{array}{l}\text { Post-hospital discharge for } \\
\text { up to } 3 \text { months }\end{array}$ & I (5.9) & [44] \\
\hline $\begin{array}{l}\text { Post-hospital discharge for } \\
\text { up to } 6 \text { months }\end{array}$ & $3(17.6)$ & {$[19,41,42]$} \\
\hline
\end{tabular}

(Continued)
Table I (Continued).

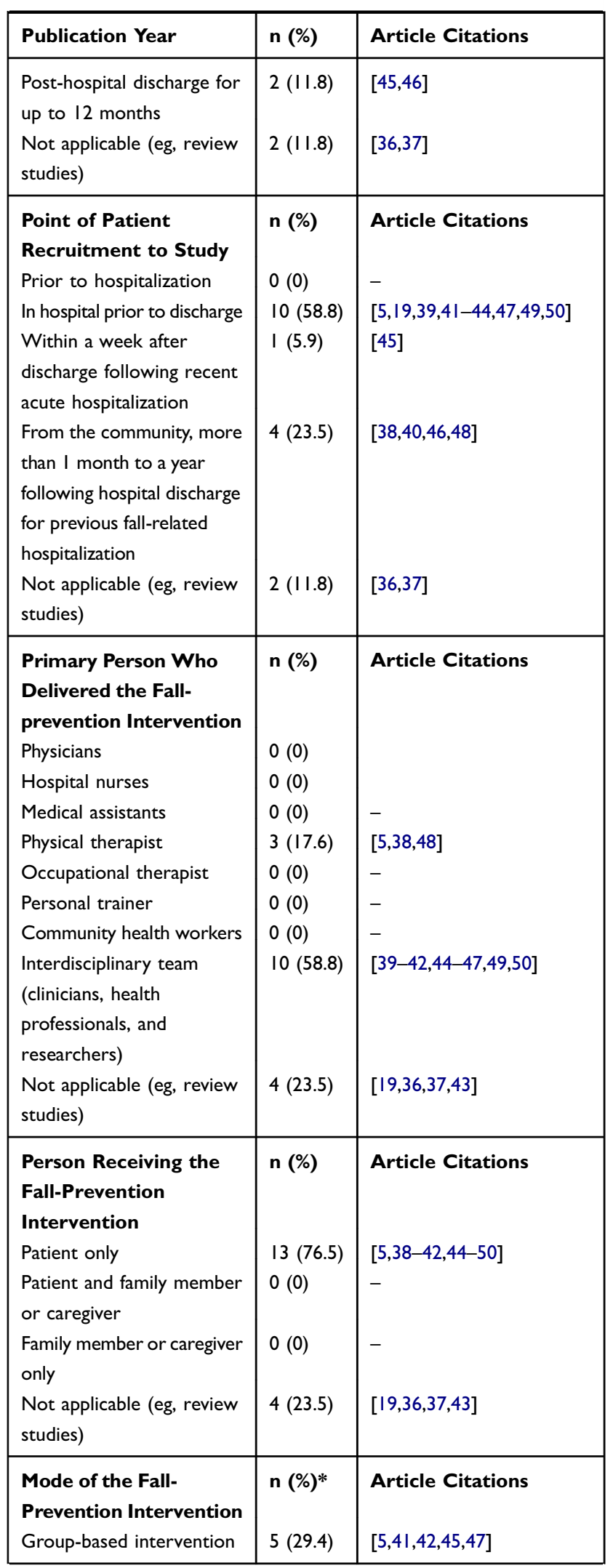

(Continued) 
Table I (Continued).

\begin{tabular}{|l|l|l|}
\hline Publication Year & n (\%) & Article Citations \\
\hline $\begin{array}{l}\text { Individual-based } \\
\text { intervention }\end{array}$ & $7(4 I .2)$ & {$[38-40,44,48-50]$} \\
$\begin{array}{l}\text { Follow-up events (by } \\
\text { telephone, mail, e-mail) } \\
\text { Social network (eg, } \\
\text { Facebook) } \\
\text { Self-monitoring devices } \\
\text { (eg, Smartphone, Fitbit, }\end{array}$ & $0(52.9)$ & $0(0)$ \\
$\begin{array}{l}\text { Apple Watch) } \\
\text { Home technologies or } \\
\text { internet-of-things (eg, } \\
\text { blood pressure cuff, weight } \\
\text { scale) }\end{array}$ & $0(0)$ & - \\
$\begin{array}{l}\text { Not applicable (eg, review } \\
\text { studies) }\end{array}$ & $4(23.5)$ & {$[19,36,37,42,46,47,49,50]$} \\
\hline
\end{tabular}

Notes: *Multiple modes of fall-prevention overlap for cited studies. The frequency is the number of cited articles per category. The percentage is the percentage of the 17 articles included in the review.

and three in the United Kingdom. ${ }^{36,40,44}$ Six (35.3\%) used qualitative methods, ${ }^{36,38,40,44,49,50}$ six $(35.3 \%)$ used mixed methods, ${ }^{19,37,41-43,46}$ and five (29.4\%) used quantitative methods. ${ }^{5,39,45,47,48}$ Five (29.4\%) targeted post-hospital discharge for up to 1 month, $5,39,43,47,50$ and three (17.6\%) targeted post-hospital discharge for up to 6 months. ${ }^{19,41,42}$

Ten studies $(58.8 \%)$ recruited patients during hospital stays; $5,19,39,41-44,47,49,50$ four (23.5\%) recruited patients from the community. ${ }^{38,40,46,48}$ In ten studies $(58.8 \%)$, an interdisciplinary team delivered the fallprevention intervention. ${ }^{39-42,44-47,49,50}$ Thirteen studies $(76.5 \%)$ included only patients as the fall-prevention intervention recipients. ${ }^{5,38-42,44-50}$ Four studies were review studies. ${ }^{19,36,37,43}$ For the intervention, nine studies $(52.9 \%)$ included follow-up events by phone, mail or e-mail. $5,38,39,41,42,46,47,49,50$ Seven studies (41.2\%) used individual-based interventions, ${ }^{38-40,44,48-50}$ and five $(29.4 \%)$ used group-based interventions. ${ }^{5,41,42,45,47}$

\section{Individual Evidence Sources}

Table 2 summarizes the characteristics of the included studies.

\section{Synthesis of the Results}

Table 3 presents the barriers to older adults participating in fall-prevention strategies post-hospital discharge, and Table 4 presents the facilitators. Barriers and facilitators were categorized by frequency of occurrence. Results (themes) in Tables 3 and 4 were coded with identifiers corresponding to the COM-B framework, ${ }^{34,35}$ where " $\mathrm{C}$ " refers to capability, "O", opportunity and "M", motivation for the respective barriers and facilitators. Subthemes were similarly categorized under major themes using the same coding strategy.

\section{Barriers}

Four themes were identified as capability-related barriers: frailty due to advancing age, $36,39,43,46,51$ language and communication, ${ }^{40,41,43,46}$ education/literacy levels, ${ }^{43,46}$ and health-related problems (Table 3). ${ }^{36,37,40,42,46,47,49}$ Physical health $37,42,46$ and general health issues $36,40,47,49$ were the most frequently mentioned capability-related barriers limiting participation in fall-prevention interventions (7 studies, 41.2\%). ${ }^{36,37,40,42,46,47,49}$

Four themes were identified as opportunity-related barriers: lack of institutional support, ${ }^{37,38,40-43,46,49}$ lack of social and community support, ${ }^{37}$ fall-prevention strategies requiring additional designs, ${ }^{19,41,42,49}$ and lack of access to intervention. $^{36,40,48,49}$ Eight studies ${ }^{37,38,40-43,46,49}$ (47.1\%) implied lack of institutional support for fall-prevention programs as the most common opportunity-related barrier; five of these studies ${ }^{37,38,40,42,49}$ mentioned that health staff were disinterested in promoting fall-prevention interventions due to heavy clinical workload ${ }^{37,38,52}$ and lack of understanding the program. ${ }^{37,40,42}$

Four themes were identified as motivation-related barriers: lack of motivation to carry out or sustain involvement in the fall-prevention intervention post-hospital discharge or during hospitalization, ${ }^{36,37,41-44,48,49}$ self-denial of risk for falls, ${ }^{36,50}$ difficulty transitioning between daily living activities and fall-prevention strategies, ${ }^{36}$ and enthusiasm fatigue. $^{37}$ The most frequently mentioned motivationrelated barrier was lack of motivation ${ }^{36,37,41-44,48,49}$ (8 articles, $47.1 \%$ ), which included lack of motivation to participate because of emotional/mental-related issues, ${ }^{43,49}$ lacking the will to join because of spiritual beliefs conflicting with fall-prevention practice (eg, practicing Tai-Chi may interfere with spiritual beliefs), ${ }^{37}$ behavior and attitudes towards fall-prevention hindering participation (eg, overconfident in their ability to prevent falls) $36,37,41,42,44,48$ and older adults lacking confidence to prevent falls. ${ }^{48,49}$

\section{Facilitators}

Four themes were identified and categorized as capabilityrelated facilitators: being younger older adults (because 
Table 2 Characteristics of the Included Studies $(n=17)$

\begin{tabular}{|c|c|c|c|c|}
\hline Article & $\begin{array}{l}\text { Aim/Study } \\
\text { Outcome }\end{array}$ & $\begin{array}{l}\text { Participants/ } \\
\text { Inclusion Criteria }\end{array}$ & Methods & Findings \\
\hline $\begin{array}{l}\text { Agmon } \\
\text { et al, } \\
2016^{47}\end{array}$ & $\begin{array}{l}\text { To determine the } \\
\text { association between } \\
\text { pre-diagnosed } \\
\text { anxiety during } \\
\text { hospitalization and } \\
\text { falls I-month post- } \\
\text { discharge. }\end{array}$ & $\begin{array}{l}\text { Older adults aged } \\
\geq 70 \text { years pre- } \\
\text { diagnosed with } \\
\text { anxiety, no loss of } \\
\text { cognitive function } \\
\text { and no disabling } \\
\text { diagnosis }(\mathrm{N}=556) \text {. }\end{array}$ & $\begin{array}{l}\text { Post-discharge data } \\
\text { collected } \\
\text { retrospectively by } \\
\text { telephone } \\
\text { interviews/surveys. } \\
\text { Data analyzed using } \\
\text { logistic regression } \\
\text { studies. }\end{array}$ & $\begin{array}{l}\text { Older adults } \geq 70 \text { years with prediagnosed anxiety were twice as } \\
\text { likely to fall } 30 \text { days post-discharge after acute hospitalization } \\
\text { than were older adults without prehospitalization anxiety } \\
\text { (adjusted odds ratio=1.89; } 95 \% \mathrm{Cl}: 1.04-3.48 \text { ). }\end{array}$ \\
\hline $\begin{array}{l}\text { Calhoun } \\
\text { et al, } \\
2011^{38}\end{array}$ & $\begin{array}{l}\text { To investigate } \\
\text { barriers and } \\
\text { facilitators to } \\
\text { participating in fall- } \\
\text { risk assessment } \\
\text { programs among } \\
\text { older adults who had } \\
\text { fallen. }\end{array}$ & $\begin{array}{l}\text { Older adults aged } \\
\geq 75 \text { years recruited } \\
\text { from a list of fall-risk } \\
\text { assessment programs } \\
(\mathrm{N}=39) .\end{array}$ & $\begin{array}{l}\text { Interview guide with } \\
\text { open-ended } \\
\text { questions to } \\
\text { stimulate } \\
\text { conversations around } \\
\text { facilitators and } \\
\text { barriers to } \\
\text { participation. Data } \\
\text { analyzed using } \\
\text { thematic analysis. }\end{array}$ & $\begin{array}{l}\text { Study findings under facilitators and barriers to participation } \\
\text { included: } \\
\text { I) Perception of need: differentiated between participators } \\
\text { and non-participators. Participants expressed that they } \\
\text { "needed" the program, while nonparticipants expressed a } \\
\text { lack of need for the fall-prevention programs because they } \\
\text { prevented falling themselves by being more careful. } \\
\text { 2) Transportation: Lack of transportation was a barrier to } \\
\text { participating as it affected older adults who were assigned to } \\
\text { programs in community clinics. }\end{array}$ \\
\hline $\begin{array}{l}\text { Davenport } \\
\text { et al, } \\
2009^{39}\end{array}$ & $\begin{array}{l}\text { To investigate the fall } \\
\text { rate of in-hospital } \\
\text { fallers post-discharge } \\
\text { and explore their } \\
\text { risk factors for falling } \\
\text { during the period } \\
\text { immediately after } \\
\text { hospital discharge. }\end{array}$ & $\begin{array}{l}\text { Younger and older } \\
\text { adults who had fallen } \\
\text { during hospitalization, } \\
\text { English-speaking, had } \\
\text { not been to a nursing } \\
\text { home before } \\
\text { hospitalization, would } \\
\text { not be discharged to a } \\
\text { nursing home, life } \\
\text { expectancy } \geq 3 \\
\text { months, discharged } \\
\text { home, had a phone, } \\
\text { and were cognitive to } \\
\text { give consent ( } \mathrm{N}=65 \text { ). }\end{array}$ & $\begin{array}{l}\text { Data regarding fall } \\
\text { frequency and factors } \\
\text { enabling falls at home } \\
\text { were collected } 4 \\
\text { weeks post-discharge } \\
\text { through telephone } \\
\text { surveys and analyzed } \\
\text { quantitatively and } \\
\text { qualitatively. }\end{array}$ & $\begin{array}{l}\text { Self or caregiver reported falls at home } 4 \text { weeks post-discharge } \\
19 \text { participants suffered } 38 \text { falls with a fall rate estimated as } 25.4 \\
1000 \text { person-days ( } 95 \% \mathrm{Cl}=17.3-33.4 \text { ) for adult participants } \\
\text { aged } 22-97 \text { years (mean } 65.5 \text { years } \pm 13 \text { ). However, fall rates } \\
\text { between age groups }<64 \text { years and } \geq 65 \text { years were } 25.5 \text { falls/ } \\
1000 \text { person-days and } 25.2 \text { falls/ } 1000 \text { person-days, respectively } \\
\text { The study also recorded } 3 \text { mortalities and } 4 \text { nursing home } \\
\text { referrals for rehabilitation therapy. Risk factors for falls post- } \\
\text { discharge did not statistically significantly differ between fallers } \\
\text { and non-fallers controlled for all categories (age, use of mobility } \\
\text { aids, previous hospitalizations, previous fall histories, fall injuries } \\
\text { during hospitalization, and duration of hospitalization). } \\
\text { However, after controlling for sex, fall rates post-discharge were } \\
\text { higher among adults who fell more than once during } \\
\text { hospitalization ( }(\mathrm{p}=0.001 \text { ). }\end{array}$ \\
\hline $\begin{array}{l}\text { Dickinson } \\
\text { et al, } \\
2011^{40}\end{array}$ & $\begin{array}{l}\text { To investigate older } \\
\text { adults' perceptions of } \\
\text { facilitators and } \\
\text { barriers to } \\
\text { participating in fall- } \\
\text { prevention } \\
\text { interventions }\end{array}$ & $\begin{array}{l}\text { Older adults aged } \geq 60 \\
\text { years living within a } \\
\text { community setting } \\
\text { and had experienced } \\
\text { at least one fall- } \\
\text { prevention } \\
\text { intervention (eg, fall } \\
\text { clinics, postural } \\
\text { stability classes, Tai- } \\
\text { Chi, and exercise } \\
\text { classes). Participants } \\
\text { were recruited by } \\
\text { letters and personal } \\
\text { invitations ( } \mathrm{N}=\text { I87). }\end{array}$ & $\begin{array}{l}\text { Seventeen focus } \\
\text { groups with } 122 \\
\text { participants and } \\
\text { individual interviews } \\
\text { for the rest ( } n=65 \text { ). } \\
\text { Data were analyzed } \\
\text { for content and } \\
\text { themes. }\end{array}$ & $\begin{array}{l}\text { Major findings included: } \\
\text { I. Health professional response: Participants felt health profes- } \\
\text { sionals lacked interest in talking about falls; therefore, they } \\
\text { failed to refer them to the right interventions. } \\
\text { 2. Inadequate assessment from health-care professionals who } \\
\text { failed to assess the extent of older adult fall risks and fall } \\
\text { injuries, only to be picked up at a later date from complica- } \\
\text { tions in other body systems. } \\
\text { 3. Poor access to healthcare when needed: lack of doctors in the } \\
\text { community when patients had emergencies. } \\
\text { 4. Doctors acting as barriers by showing disinterest and } \\
\text { delinquency. } \\
\text { 5. Language barriers: Some non-English-speaking doctors } \\
\text { deterred patients because of poor communication. }\end{array}$ \\
\hline
\end{tabular}

(Continued) 
Table 2 (Continued).

\begin{tabular}{|c|c|c|c|c|}
\hline Article & $\begin{array}{l}\text { Aim/Study } \\
\text { Outcome }\end{array}$ & $\begin{array}{l}\text { Participants/ } \\
\text { Inclusion Criteria }\end{array}$ & Methods & Findings \\
\hline $\begin{array}{l}\text { Finnegan } \\
\text { et al, } \\
2019^{36}\end{array}$ & $\begin{array}{l}\text { A systematic review } \\
\text { of qualitative studies } \\
\text { to explore the } \\
\text { barriers and } \\
\text { facilitators to } \\
\text { continued } \\
\text { participation in fall- } \\
\text { prevention exercise } \\
\text { programs }\end{array}$ & $\begin{array}{l}\text { Community-dwelling } \\
\text { older adults aged } \geq 65 \\
\text { years who had } \\
\text { participated in a fall- } \\
\text { prevention exercise } \\
\text { program. }\end{array}$ & $\begin{array}{l}\text { Data extracted from } \\
\text { identified articles } \\
\text { included aim, } \\
\text { participant } \\
\text { characteristics, } \\
\text { method of data } \\
\text { collection, } \\
\text { methodology, and } \\
\text { analysis. All data } \\
\text { extracted were } \\
\text { thematically analyzed } \\
\text { and used to integrate } \\
\text { findings. }\end{array}$ & 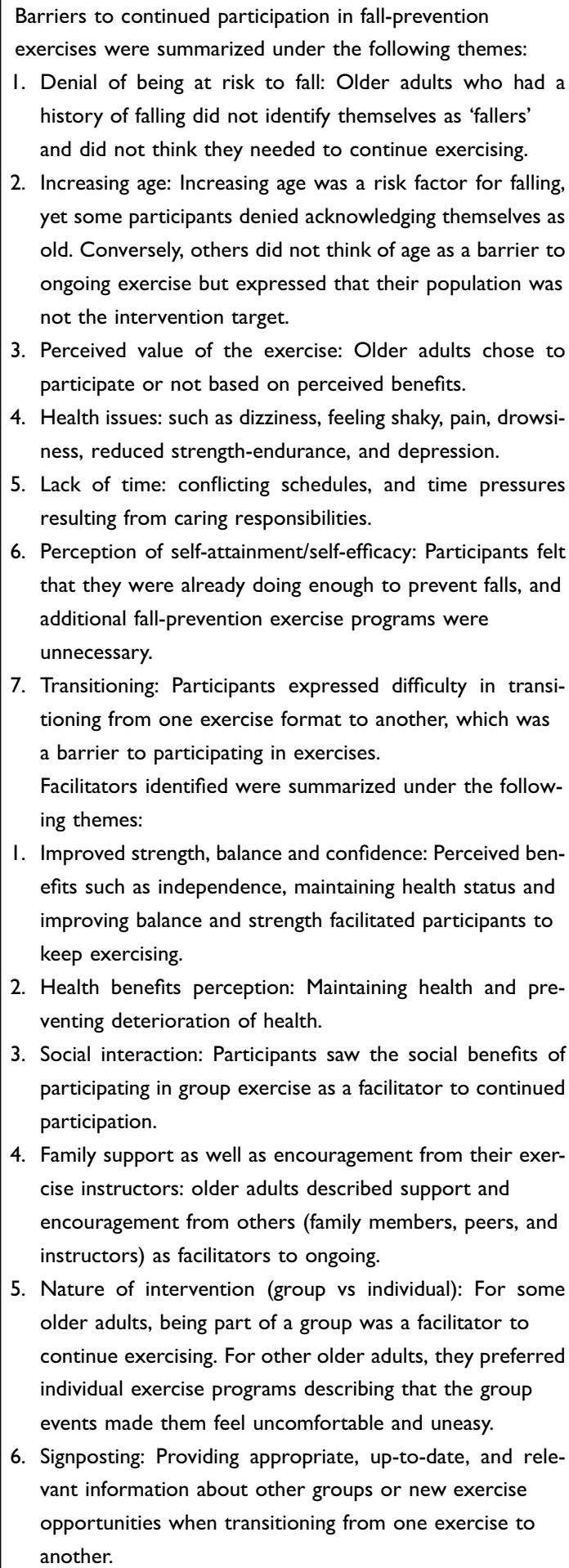 \\
\hline
\end{tabular}

(Continued) 
Table 2 (Continued).

\begin{tabular}{|c|c|c|c|c|}
\hline Article & $\begin{array}{l}\text { Aim/Study } \\
\text { Outcome }\end{array}$ & $\begin{array}{l}\text { Participants/ } \\
\text { Inclusion Criteria }\end{array}$ & Methods & Findings \\
\hline $\begin{array}{l}\text { Hill et al, } \\
201 I^{4 I}\end{array}$ & $\begin{array}{l}\text { RCT to examine } \\
\text { whether older adults } \\
\text { were ready to } \\
\text { engage in fall- } \\
\text { prevention strategies } \\
\text { following hospital } \\
\text { discharge } \\
\text { The study outcome } \\
\text { was to identify what } \\
\text { fall-prevention } \\
\text { strategy participants } \\
\text { perceived would } \\
\text { reduce their risk for } \\
\text { in the first } 6 \text { months } \\
\text { following discharge. }\end{array}$ & $\begin{array}{l}\text { Older adults aged } \\
\geq 60 \text { years discharged } \\
\text { following acute } \\
\text { hospitalization or } \\
\text { subacute } \\
\text { rehabilitation for } \\
\text { conditions such as } \\
\text { orthopedic, } \\
\text { pulmonary, stroke, } \\
\text { and cardiac } \\
\text { conditions. } \\
\text { Participants ( } \mathrm{N}=333 \text { ) } \\
\text { were randomized } \\
\text { into } 3 \text { groups. Two } \\
\text { groups received a } \\
\text { multimedia package } \\
\text { containing fall- } \\
\text { prevention education } \\
\text { specific to their } \\
\text { condition, and the } \\
\text { control group } \\
\text { received standard } \\
\text { care. }\end{array}$ & $\begin{array}{l}\text { Semi-structured } \\
\text { interviews were } \\
\text { administered } 48 \\
\text { hours before } \\
\text { discharge. Data } \\
\text { analyzed for } \\
\text { descriptive outcomes } \\
\text { and themes. }\end{array}$ & $\begin{array}{l}\text { Findings were described under the following thematic } \\
\text { headings: } \\
\text { I. Behavioral: Participants described behavioral strategies to } \\
\text { reduce falls. Quotations included, "being careful", "getting } \\
\text { help" and "not taking risks." } \\
\text { 2. Support while mobilizing: Using supportive equipment or } \\
\text { items to remain upright. } \\
\text { 3. Approach to movement: Considered movement concepts } \\
\text { that cause falls such moving too fast or turning too quickly. } \\
\text { 4. Physical environment: Modification of physical home envir- } \\
\text { onments such as removing clutter and obstacles. } \\
\text { 5. Visual: Being alert about one's immediate environment (eg, } \\
\text { looking where one is going or watching for different } \\
\text { surfaces). } \\
\text { 6. Medical: Medical suggestions older adult thought might } \\
\text { reduce their fall risks. For example, "checking for dizzi- } \\
\text { ness and being aware of medication side effects on } \\
\text { balance." } \\
\text { 7. Activity and exercise: Participants' suggestions for improv- } \\
\text { ing physical capability such as, "going for walks," and "doing } \\
\text { strength and balance building exercises." }\end{array}$ \\
\hline $\begin{array}{l}\text { Hill et al, } \\
2011^{42}\end{array}$ & $\begin{array}{l}\text { RCT to identify } \\
\text { factors associated } \\
\text { with older adults' } \\
\text { exercising } 6 \text { months } \\
\text { after hospital } \\
\text { discharge. } \\
\text { Study outcomes } \\
\text { were: I) older adults' } \\
\text { attitudes and beliefs } \\
\text { about falls, 2) older } \\
\text { adults' engagement in } \\
\text { structured exercises } \\
\text { (ie, exercise that } \\
\text { increased balance } \\
\text { and strength), and } 3 \text { ) } \\
\text { Perceived barriers to } \\
\text { engaging in } \\
\text { structured exercise } \\
\text { after discharge. }\end{array}$ & $\begin{array}{l}\text { Older adults } \geq 60 \\
\text { years old recently } \\
\text { discharged from } 4 \\
\text { participating wards } \\
\text { (medical, surgical, } \\
\text { stroke, or } \\
\text { rehabilitation wards) } \\
\text { in a general hospital. } \\
\text { Of these, } 343 \\
\text { consented to } \\
\text { participate and were } \\
\text { randomized to } 2 \\
\text { groups. One group } \\
\text { received fall- } \\
\text { prevention } \\
\text { education, and the } \\
\text { control group } \\
\text { received standard } \\
\text { care. }\end{array}$ & $\begin{array}{l}\text { Data were collected } \\
48 \text { hours before } \\
\text { discharge. Follow-up } \\
\text { data came from semi- } \\
\text { structured telephone } \\
\text { interviews at } 6 \\
\text { months }\end{array}$ & $\begin{array}{l}\text { Barriers to engaging in exercise post-discharge included: } \\
\text { I) attitudes toward exercise, including low self-efficacy, } \\
\text { believing that exercise was unnecessary, safety concerns } \\
\text { while exercising, insufficient motivation, dislike for exercise, } \\
\text { no need for exercise, no cue to actions during exercise, and } \\
\text { being fearful of engaging in exercise, 2) medical barriers to } \\
\text { exercise: pain from first attempts at exercising extending up } \\
\text { to } 6 \text { months post-discharge, shortness of breath on exertion, } \\
\text { feeling unwell, 3) reduced mobility from surgery, and 4) } \\
\text { exercise program delivery, for example, not being assigned to } \\
\text { an exercise program, not being able to get to the class, or } \\
\text { abrupt exercise therapy cessation. }\end{array}$ \\
\hline
\end{tabular}

(Continued) 
Table 2 (Continued).

\begin{tabular}{|c|c|c|c|c|}
\hline Article & $\begin{array}{l}\text { Aim/Study } \\
\text { Outcome }\end{array}$ & $\begin{array}{l}\text { Participants/ } \\
\text { Inclusion Criteria }\end{array}$ & Methods & Findings \\
\hline $\begin{array}{l}\text { Hill et al, } \\
2013^{5}\end{array}$ & $\begin{array}{l}\text { RCT pilot study to } \\
\text { evaluate the effects of } \\
\text { providing tailored fall- } \\
\text { prevention education } \\
\text { in hospital on engaging } \\
\text { in fall-prevention } \\
\text { strategies I month } \\
\text { after discharge. } \\
\text { The study outcomes } \\
\text { were a measure of I) } \\
\text { older adults' } \\
\text { engagement in fall- } \\
\text { prevention strategies } \\
\text { I month after } \\
\text { discharge and 2) } \\
\text { perceived risk about } \\
\text { falls and fall-prevention } \\
\text { strategies to engage in } \\
\text { after discharge. }\end{array}$ & $\begin{array}{l}\text { Hospital older adult } \\
\text { patients aged } \geq 60 \\
\text { years scheduled to be } \\
\text { discharged from } \\
\text { stroke or } \\
\text { rehabilitation wards } \\
\text { to home ( } \mathrm{N}=50) \text {. } \\
\text { Participants were } \\
\text { randomized into an } \\
\text { intervention group } \\
\text { with a tailored } \\
\text { multimedia fall- } \\
\text { prevention education } \\
\text { package, follow-up } \\
\text { and additional care, } \\
\text { and a control group } \\
\text { with usual care. }\end{array}$ & $\begin{array}{l}\text { Data were collected } \\
24 \text { hours prior to } \\
\text { discharge and at I- } \\
\text { month post- } \\
\text { discharge via } \\
\text { telephone using semi- } \\
\text { structured survey } \\
\text { tools. }\end{array}$ & $\begin{array}{l}\text { The intervention group was significantly more likely to safely } \\
\text { restart functional activities (adjusted odds ratio } 3.80,95 \% \mathrm{C} \\
{[1.07,13.52], \mathrm{p}=0.04 \text { ) and more likely to complete targeted }} \\
\text { fall preventive behaviors (adjusted odds ratio } 2.76,95 \% \mathrm{Cl} \\
{[0.72,10.50], \mathrm{p}=0.14 \text { ) than the control group. The }} \\
\text { intervention group was significantly more knowledgeable, } \\
\text { confident, and motivated to engage in fall-prevention } \\
\text { strategies post-education intervention compared with the } \\
\text { control group. }\end{array}$ \\
\hline $\begin{array}{l}\text { Kiami et al, } \\
2019^{48}\end{array}$ & $\begin{array}{l}\text { To identify factors } \\
\text { that increase the } \\
\text { likelihood of enrolling } \\
\text { in fall-prevention } \\
\text { programs among } \\
\text { community-dwelling } \\
\text { older adults. }\end{array}$ & $\begin{array}{l}\text { Older adults aged } \\
\geq 60 \text { years, residing in } \\
\text { the community who } \\
\text { could read and write } \\
\text { English. }\end{array}$ & $\begin{array}{l}\text { Semi-structured } \\
\text { survey questionnaires } \\
\text { used to collect data. } \\
\text { Data analyzed using } \\
\text { chi-square tests and } \\
\text { logistic regression } \\
\text { analysis. }\end{array}$ & $\begin{array}{l}\text { Four barriers were associated with less likelihood to enroll in fall- } \\
\text { prevention programs: I) belief will not fall, 2) lack of time, 3) } \\
\text { transportation, 4) will not prevent falling, and 5) not offered } \\
\text { nearby. } \\
\text { Seven facilitators were associated with more likely to enroll in } \\
\text { fall-prevention programs: I) offered near home, 2) free vision } \\
\text { screening, 3) friendly leader, 4) coffee hour to socialize, 5) no } \\
\text { cost, 6) group exercise, and 7) safe space/place }\end{array}$ \\
\hline $\begin{array}{l}\text { Lee et al, } \\
2013^{43}\end{array}$ & $\begin{array}{l}\text { Systematic review and } \\
\text { meta-analyses to } \\
\text { assess the } \\
\text { effectiveness of patient } \\
\text { education in reducing } \\
\text { falls, promoting } \\
\text { behavioral change, and } \\
\text { taking up fall- } \\
\text { prevention activities } \\
\text { during and after } \\
\text { hospitalization. } \\
\text { Primary outcome: } \\
\text { Proportion of older } \\
\text { adults who were } \\
\text { hospital or post- } \\
\text { hospital fallers. } \\
\text { Secondary outcome: } \\
\text { Awareness of fall and } \\
\text { fall-prevention } \\
\text { strategies. }\end{array}$ & $\begin{array}{l}\text { Studies with older } \\
\text { adults aged } \geq 60 \text { years } \\
\text { involved in patient } \\
\text { education as a single } \\
\text { or multifactorial } \\
\text { intervention in } \\
\text { hospital or post- } \\
\text { discharge. }\end{array}$ & $\begin{array}{l}\text { Data were collated } \\
\text { from identified } \\
\text { library databases, } \\
\text { screened for } \\
\text { inclusion, and } \\
\text { thematically analyzed } \\
\text { for facilitators and } \\
\text { barriers to fall } \\
\text { prevention. }\end{array}$ & $\begin{array}{l}\text { Barriers identified included I) lack of fall-prevention } \\
\text { education, 2) perceiving falls as unpreventable, 3) cluttered } \\
\text { environment, 4) chronic diseases, 5) unavailability of walking } \\
\text { aids, } 6 \text { ) advancing age, 7) lower educational or literacy levels, } \\
\text { 8) lack of social support, and 9) cognitive and communication } \\
\text { problems. Facilitators identified included I) patient education } \\
\text { on falls, 2) cues to action: recommendations made by health } \\
\text { professionals, 3) self-efficacy using visual learning aids, and 4) } \\
\text { location and prolonged engagement: attitudes and beliefs } \\
\text { regarding falls and prevention influenced positively by } \\
\text { location (eg, hospital-based studies demonstrated positive } \\
\text { attitudes to change following fall education due to the } \\
\text { intensity of the education provided). }\end{array}$ \\
\hline
\end{tabular}

(Continued) 
Table 2 (Continued).

\begin{tabular}{|c|c|c|c|c|}
\hline Article & $\begin{array}{l}\text { Aim/Study } \\
\text { Outcome }\end{array}$ & $\begin{array}{l}\text { Participants/ } \\
\text { Inclusion Criteria }\end{array}$ & Methods & Findings \\
\hline $\begin{array}{l}\text { McMillan } \\
\text { et al, } \\
2014^{44}\end{array}$ & $\begin{array}{l}\text { Used grounded } \\
\text { theory to explore } \\
\text { the post-discharge } \\
\text { concerns of older } \\
\text { adults after fall- } \\
\text { induced hip } \\
\text { fractures. }\end{array}$ & $\begin{array}{l}\text { Older adults aged } \\
\geq 65 \text { years living at } \\
\text { home who had been } \\
\text { discharged for up to } \\
3 \text { months }(\mathrm{N}=19) \text {. }\end{array}$ & $\begin{array}{l}\text { Data collected using } \\
\text { semi-structured } \\
\text { qualitative interview } \\
\text { guides and analyzed } \\
\text { using a constant } \\
\text { comparison method } \\
\text { of the Glaserian } \\
\text { method. }\end{array}$ & $\begin{array}{l}\text { A theory of 'taking control' was developed to explain the } \\
\text { coping mechanisms employed after falls post-discharge. The } \\
\text { key strategy to this theory was 'Balancing risk,' which older } \\
\text { adults said helped them take control after discharge. This } \\
\text { strategy was explained by key quotes like "protective } \\
\text { guarding" and "following orders." }\end{array}$ \\
\hline $\begin{array}{l}\text { Naseri } \\
\text { et al, } \\
2018^{19}\end{array}$ & $\begin{array}{l}\text { Systematic review to } \\
\text { synthesize evidence } \\
\text { for fall-prevention } \\
\text { interventions in } \\
\text { older adults } \\
\text { discharged from } \\
\text { hospital and followed } \\
\text { for } 6 \text { months. }\end{array}$ & $\begin{array}{l}\text { I) Studies involving } \\
\text { older adults aged } \geq 60 \\
\text { years, } 2 \text { ) studies } \\
\text { where older adults } \\
\text { were hospitalized and } \\
\text { then discharged } \\
\text { home or to a } \\
\text { community, } 30 \\
\text { studies where } \\
\text { interventions were } \\
\text { delivered in a hospital } \\
\text { or within I month } \\
\text { post-discharge, and } \\
\text { studies published } \\
\text { globally in English } \\
\text { between January } \\
1990 \text { and June } 2017 .\end{array}$ & $\begin{array}{l}\text { Data were extracted } \\
\text { from identified } \\
\text { library databases, } \\
\text { appraised for quality } \\
\text { using the JBI critical } \\
\text { appraisal tool and } \\
\text { pooled for meta- } \\
\text { analyses using } \\
\text { RevMan review } \\
\text { manager. Synthesized } \\
\text { studies were } \\
\text { evaluated and } \\
\text { categorized using the } \\
\text { summary of } \\
\text { evidence. }\end{array}$ & $\begin{array}{l}\text { Selected studies reported synthesized evidence for the } \\
\text { following fall interventions shown to reduce falls post- } \\
\text { discharge: I) Home hazard modification (I study; low-grade } \\
\text { evidence), 2) Home exercise ( } 3 \text { studies, moderate GRADE } \\
\text { evidence), and 3) Short-term nutritional supplementation (I } \\
\text { study; low-grade evidence). }\end{array}$ \\
\hline $\begin{array}{l}\text { Sandlund } \\
\text { et al, } \\
2017^{37}\end{array}$ & $\begin{array}{l}\text { Systematic review to } \\
\text { explore underlying } \\
\text { gender perspectives } \\
\text { or interpretations of } \\
\text { older adults' } \\
\text { preferences } \\
\text { regarding uptake and } \\
\text { adherence to } \\
\text { exercise to prevent } \\
\text { falls. }\end{array}$ & $\begin{array}{l}\text { Qualitative, } \\
\text { quantitative, or } \\
\text { mixed-method } \\
\text { studies involving } \\
\text { older adults aged } \geq 60 \\
\text { years, community- } \\
\text { dwelling or living in } \\
\text { residential homes, } \\
\text { presenting views on } \\
\text { fall-prevention } \\
\text { exercise strategies. }\end{array}$ & $\begin{array}{l}\text { Data were collated } \\
\text { from identified } \\
\text { library databases, } \\
\text { screened for } \\
\text { inclusion, and } \\
\text { analyzed using } \\
\text { constant comparison } \\
\text { to create themes for } \\
\text { facilitators and } \\
\text { barriers to fall- } \\
\text { prevention. }\end{array}$ & $\begin{array}{l}\text { Barriers to participating in fall-prevention exercise were } \\
\text { categorized into six themes: I) practical issues } \\
\text { (transportation, lack of time, bad weather, and lack of a } \\
\text { suitable place to exercise at home); 2) concerns about } \\
\text { exercise (lack of confidence to exercise, fear of adverse } \\
\text { effects, not being able to keep up, dislike for group exercise); } \\
\text { 3) unawareness (lack of knowledge about the benefits of } \\
\text { exercise to fall prevention, perception of being active enough } \\
\text { to need exercise, and denial of fall risk); 4) reduced health } \\
\text { status (eg, pain and fatigue); 5) lack of support; and 6) lack of } \\
\text { interest (for group versus individual exercise programs). } \\
\text { Facilitators included I) support from professionals or family; } \\
\text { 2) social interaction; 3) perceived benefits, 4) supportive } \\
\text { exercise context; 5) feelings of commitment; and 6) having } \\
\text { fun. }\end{array}$ \\
\hline
\end{tabular}

(Continued) 
Table 2 (Continued).

\begin{tabular}{|c|c|c|c|c|}
\hline Article & $\begin{array}{l}\text { Aim/Study } \\
\text { Outcome }\end{array}$ & $\begin{array}{l}\text { Participants/ } \\
\text { Inclusion Criteria }\end{array}$ & Methods & Findings \\
\hline $\begin{array}{l}\text { Shuman } \\
\text { et al, } \\
2016^{49}\end{array}$ & $\begin{array}{l}\text { To describe } \\
\text { hospitalized older } \\
\text { adults' perceptions } \\
\text { about I) their fall } \\
\text { risks while } \\
\text { hospitalized; 2) } \\
\text { interventions they } \\
\text { received to prevent } \\
\text { falls while } \\
\text { hospitalized; and 3) } \\
\text { the instructions } \\
\text { received at discharge } \\
\text { to prevent falls at } \\
\text { home. }\end{array}$ & $\begin{array}{l}\text { Older adults aged } \\
\geq 60 \text { years, } \\
\text { hospitalized in the } \\
\text { study unit for at least } \\
48 \text { hours, classified as } \\
\text { at-risk-for-falls } \\
\text { patients based on } \\
\text { Morse fall score, have } \\
\text { a phone number, } \\
\text { English-speaking, and } \\
\text { medically stable } \\
\text { ( } N=18) .\end{array}$ & $\begin{array}{l}\text { Data collected in- } \\
\text { hospital and post- } \\
\text { discharge interviews } \\
\text { by telephone. Data } \\
\text { analyzed using } \\
\text { constant comparative } \\
\text { methods to delineate } \\
\text { and resolve } \\
\text { conflicting themes. }\end{array}$ & $\begin{array}{l}\text { Barriers identified in the thematic analysis were I) fear of falling } \\
\text { for those at risk of falling, 2) misunderstanding or non- } \\
\text { acknowledgment of fall-prevention procedures by healthcare } \\
\text { staff causing patients not to pay attention to their fall risk or } \\
\text { adopt/comply with interventions, 3) generalized fall-prevention } \\
\text { interventions not fitting for outlying patients, 4) perception of } \\
\text { fall-related discharge instructions (some forget they were told } \\
\text { what to do post-discharge), and 5) mobility issues and } \\
\text { compliance especially for those using walking aids without } \\
\text { support or assistance. Facilitators identified included I) tailored } \\
\text { fall-prevention interventions, 2) satisfaction with fall-prevention } \\
\text { interventions, 3) reminders of fall-prevention interventions, 4) } \\
\text { family support and assistance, 5) effectiveness of fall prevention } \\
\text { (as defined by research evidence) of the fall-prevention } \\
\text { intervention, and 6) verbal and written discharge prescriptions }\end{array}$ \\
\hline $\begin{array}{l}\text { Shuman } \\
\text { et al, } \\
2019^{50}\end{array}$ & $\begin{array}{l}\text { To describe I) the } \\
\text { risks for falls, factors } \\
\text { contributing to fall } \\
\text { risks and actions to } \\
\text { prevent falls at home, } \\
\text { 2) information } \\
\text { received at discharge } \\
\text { to prevent falls at } \\
\text { home; and 3) } \\
\text { awareness and } \\
\text { perceptions regarding } \\
\text { the usefulness of CDC } \\
\text { STEADI fall- } \\
\text { prevention brochures } \\
\text { in recently } \\
\text { hospitalized older } \\
\text { adults }\end{array}$ & $\begin{array}{l}\text { a) Older adults aged } \\
\geq 60 \text { years, b) } \\
\text { identified as } \\
\text { moderate-to-high } \\
\text { risk for falls by Morse } \\
\text { fall score, during } \\
\text { recent } \\
\text { hospitalization, c) } \\
\text { discharged home } \\
\text { after acute } \\
\text { hospitalization, d) } \\
\text { English-speaking, and } \\
\text { e) able to participate } \\
\text { in interview } 4 \text { weeks } \\
\text { post-hospital } \\
\text { discharge }(N=9) \text {. }\end{array}$ & $\begin{array}{l}\text { Data were collected } \\
\text { via face-to-face } \\
\text { interviews lasting } \\
45-60 \text { minutes } 4 \\
\text { weeks after } \\
\text { discharge. Audio was } \\
\text { recorded and } \\
\text { analyzed using } \\
\text { inductive thematic } \\
\text { analysis for the key } \\
\text { question: 'What can } \\
\text { you do to prevent } \\
\text { falls?' Data analyzed } \\
\text { using constant } \\
\text { comparative } \\
\text { methods. }\end{array}$ & $\begin{array}{l}\text { Findings summarized in five major themes included I) } \\
\text { sedentary behaviors and limited functioning, 2) prioritization } \\
\text { of social involvement, 3) low perceived fall risk and } \\
\text { attribution of risk to external factors, 4) avoidance and } \\
\text { caution as fall-prevention and 5) limited fall-prevention } \\
\text { information when transitioning home from hospitalization. }\end{array}$ \\
\hline $\begin{array}{l}\text { Vogler } \\
\text { et al, } \\
2009^{45}\end{array}$ & $\begin{array}{l}\text { RCT to compare the } \\
\text { efficacy of seated } \\
\text { exercises compared } \\
\text { with weighted } \\
\text { exercises and social } \\
\text { visits, on fall-risk } \\
\text { factors in older } \\
\text { people recently } \\
\text { discharged from } \\
\text { hospital. } \\
\text { Study outcome: } \\
\text { Physiological profile } \\
\text { assessment (PPA) } \\
\text { composite fall risk } \\
\text { score and test of } \\
\text { ability to lean or } \\
\text { stand. }\end{array}$ & $\begin{array}{l}\text { Older adults aged } \\
\geq 65 \text { years, not } \\
\text { cognitively impaired } \\
\text { and with no } \\
\text { contraindications to } \\
\text { exercise } \\
\text { Participants }(N=180) \\
\text { were randomized } \\
\text { into } 3 \text { groups; seated } \\
\text { exercises }(n=60) \text {; } \\
\text { weight-bearing } \\
\text { exercises }(n=60) \text { and } \\
\text { social visits }(n=60) \text {. }\end{array}$ & $\begin{array}{l}\text { Data collected a few } \\
\text { days after } \\
\text { participants reached } \\
\text { home and completed } \\
3 \text { months post- } \\
\text { discharge, using self- } \\
\text { reported } \\
\text { questionnaires. }\end{array}$ & $\begin{array}{l}\text { Participants in the weight-bearing group had significantly } \\
\text { better performance than did the social visit group for PPA } \\
\text { score, coordinated stability, maximal balance range body sway } \\
\text { on the floor with eyes closed, and finger-press reaction time. } \\
\text { Similarly, the seated exercise group scored significantly better } \\
\text { than did the social visit group on PPA score only. Conversely, } \\
\text { the seated group had the highest rate of musculoskeletal } \\
\text { soreness. }\end{array}$ \\
\hline
\end{tabular}

(Continued) 
Table 2 (Continued).

\begin{tabular}{|c|c|c|c|c|}
\hline Article & $\begin{array}{l}\text { Aim/Study } \\
\text { Outcome }\end{array}$ & $\begin{array}{l}\text { Participants/ } \\
\text { Inclusion Criteria }\end{array}$ & Methods & Findings \\
\hline $\begin{array}{l}\text { Wong et al, } \\
2011^{46}\end{array}$ & $\begin{array}{l}\text { To evaluate the } \\
\text { uptake rate of a fall- } \\
\text { prevention exercise } \\
\text { program among } \\
\text { older fallers } \\
\text { discharged more } \\
\text { than } 12 \text { months from } \\
\text { acute hospitalization } \\
\text { due to related falls. }\end{array}$ & $\begin{array}{l}\text { Older adults aged } \\
\geq 60 \text { years } \\
\text { hospitalized in } \\
\text { accident and } \\
\text { emergency regional } \\
\text { hospital in Hong } \\
\text { Kong for fall-related } \\
\text { events between } \\
\text { August } 2006 \text { and } \\
\text { August } 2007 \text {. }\end{array}$ & $\begin{array}{l}\text { Data were collected } \\
\text { by telephone from all } \\
\text { previous fallers using } \\
\text { a structured } \\
\text { telephone survey } \\
\text { tool. Data were } \\
\text { analyzed using logistic } \\
\text { regression to } \\
\text { examine relationships } \\
\text { between the } \\
\text { associated factors } \\
\text { and participation in } \\
\text { the fall exercise } \\
\text { program. }\end{array}$ & $\begin{array}{l}\text { Barriers included I) lack of fall-prevention education, 2) } \\
\text { perceiving falls as being unpreventable, 3) cluttered } \\
\text { environment, 4) presence of chronic diseases, 5) unavailability } \\
\text { of walking aids, 6) advancing age, 7) lower educational or } \\
\text { literacy levels, and 8) lack of social support. } \\
\text { Facilitators were considered the reverse of the barriers } \\
\text { identified in this study. }\end{array}$ \\
\hline
\end{tabular}

they considered themselves fit and more inclined to participate), ${ }^{46}$ use of language and communication aids (eg, interpreters and audiovisual tools), ${ }^{36,41,43,46,49}$ nature of the fall-prevention strategy and personal preference, ${ }^{5,48}$ and adaptation and resiliency to new strategies aiding mobility (Table 4). ${ }^{41,46,50}$ Use of language and communication aides was the most mentioned theme (5 articles, $29.5 \%){ }^{36,41,43,46,49}$

We identified 12 themes for opportunity-related facilitators (Table 4). The first most mentioned theme was institutional and organizational support in assisting in fall-prevention programs ( 8 articles, $47.1 \%)^{36,37,40-43,49,50}$ such as providing funding and facility for the programs, ${ }^{37,42}$ providing financial incentives for health staff who educate older adults on participating in these programs, ${ }^{40}$ making available mobility support for older adults to move freely without difficulty (eg, wheelchair ramps, visual aids for slippery surfaces), ${ }^{42,46}$ and providing communication aids to facilitate comprehension. ${ }^{36,43,49,50}$ The second most mentioned theme was encouragement and social support for older adults ( 8 articles, 47\%), 5,36,37,41,44,46,48,49 such as support and empathy from family members, $5,36,37,46,49$ fall-prevention program facilitators, ${ }^{36,37,48}$ healthcare providers, ${ }^{37,41,48}$ community, ${ }^{36,37}$ and peer-to-peer support. ${ }^{37,44}$ The third most mentioned theme was prolonged community engagement and relationship building with older adults to learn how to mitigate barriers to participation (4 articles, 23.5\%). 5,36,41,48 This theme included two subthemes: (1) engaging older adults in designing fall-prevention programs collaboratively and inclusively (ie, listening to them to know what they want and learning how to meet their needs regarding preventing falls), ${ }^{5,41}$ and (2) engaging older adults respectfully and with sensitivity (eg, in considering their time/schedules, physical limitations). ${ }^{36,48}$

Three themes were identified for motivation-related facilitators: (1) following up with older adults to clarify their understanding of the fall-prevention program (2 articles, $11.8 \%),{ }^{49,50}$ (2) changing inaccurate perceptions of falls and fall-prevention strategies (5 articles, 29.4\%) ${ }^{36-38,46,50}$ such as the perception of the need for fall-prevention programs ( 1 article, $5.9 \%),{ }^{38}$ and perception of the benefits of fall-prevention programs (4 articles, 23.5\%), ${ }^{36,37,46,50}$ and (3) seeing personal gain, benefits and improvements in gait and balance ( 1 article, $5.9 \%){ }^{36}$

\section{Discussion}

This scoping review synthesized evidence regarding barriers and facilitators to older adults participating in fall-prevention strategies after transitioning home from acute hospitalization. We used the COM-B framework to categorize the barriers and facilitators in the context of behavior modifications. The success of a behavior modification involved elements of an individual's capability (physical or psychological factors), opportunities (physical, social, or institutional factors), and/or motivation (impulsive or reflective factors), ${ }^{35}$ and the findings were summarized under these three factors.

Capability factors in the COM-B framework included personal characteristics (eg, age) or intrinsic factors among 
Table 3 Barriers to Older Adults Participating in Fall-Prevention Strategies After Transitioning Home from Hospitalization ( $n=17$ Articles)

\begin{tabular}{|c|c|c|}
\hline Capability-Related Themes & Frequency $(\%)^{*}$ & Article Citation \\
\hline CI: Frailty due to advanced age & $4(23.5)$ & {$[36,39,43,46]$} \\
\hline C2: Language and communication barriers & 4 (23.5) & {$[40,41,43,46]$} \\
\hline $\begin{array}{l}\text { C2.I: Not understanding the fall-prevention program due to limitations in reading, speaking or } \\
\text { comprehension of English }\end{array}$ & I (5.9) & {$[40]$} \\
\hline C2.2: Lack of communicative channels such as visual aids, pamphlets, and reminders & I (5.9) & {$[4 I]$} \\
\hline C2.3: Use of medical jargon during communication & $2(11.8)$ & {$[43,46]$} \\
\hline C3: Literacy or educational levels associated with poor comprehension & $2(11.8)$ & {$[43,46]$} \\
\hline C4: Health-related issues limiting participation & $7(41.2)$ & {$[36,37,40,42,46,47,49]$} \\
\hline C4.I: Physical health issues (eg, joint pain, chest pain on exertion, vision) & $3(17.6)$ & {$[37,42,46]$} \\
\hline C4.2: Health issues (physical, mental, psychosocial, etc.) limiting participation & $4(23.5)$ & {$[36,40,47,49]$} \\
\hline Opportunity-Related Themes & Frequency (\%)* & Article Citation \\
\hline $\begin{array}{l}\text { OI: Lack of institutional support (eg, health, medical, and social service systems) for fall-prevention } \\
\text { program }\end{array}$ & $8(47.1)$ & {$[37,38,40-43,46,49]$} \\
\hline OI.I: Disinterest/discouragement from health staff (ie, physicians, nurses, and healthcare systems) & $5(29.4)$ & {$[37,38,40,42,49]$} \\
\hline due to heavy clinical workload, not understanding the program, or other reasons & & \\
\hline $\begin{array}{l}\text { OI.2: Lack of financial incentives for nurses, doctors or fall-prevention educators to encourage } \\
\text { active delivery and sustainability of fall-prevention programs }\end{array}$ & I (5.9) & [38] \\
\hline $\begin{array}{l}\text { OI.3: Poor organization and resources to carry out the planned activities (eg, fall-prevention } \\
\text { programs not implemented consistently to continue to engage patients in outpatient settings) }\end{array}$ & $3(17.6)$ & {$[38,42,43]$} \\
\hline $\begin{array}{l}\text { O I.4: Lack of patient safety equipment (glides, floor anti-slip mats), mobility adaptation (ramps for } \\
\text { wheelchair mobility) and mobility aids (crutches, walkers, strollers) needed to participate in fall- } \\
\text { prevention programs }\end{array}$ & $3(17.6)$ & {$[4 \mid, 46,49]$} \\
\hline $\begin{array}{l}\text { O2: Lack of social support from community, family, spouse, and peers to support fall prevention (eg, } \\
\text { older adults in the community not participating in the group exercise programs discourages other } \\
\text { older adults from participating) }\end{array}$ & I (5.9) & [37] \\
\hline $\begin{array}{l}\text { O3: Fall-prevention program requires additional design (eg, more engaging in including older adults, } \\
\text { having older adults buy in; more encompassing for all ages, genders and older adults with chronic } \\
\text { disease or disabilities) }\end{array}$ & $4(23.5)$ & {$[19,41,42,49]$} \\
\hline $\begin{array}{l}\text { O3.I: Fall-prevention programs are not comprehensive or inclusive (eg, older adults felt the } \\
\text { interventions were not patient-centered; researchers should consider older adults' preferences in } \\
\text { types of fall-prevention activities). }\end{array}$ & I (5.9) & [49] \\
\hline $\begin{array}{l}\text { O3.2: Program incompatible with older adults because it was too complex to execute (eg, virtual } \\
\text { reality exercise games) }\end{array}$ & $2(11.8)$ & {$[41,42]$} \\
\hline $\begin{array}{l}\text { O3.3: Program lacking in organization, delivery and technical support (eg, programs lacked } \\
\text { contacts to provide support or answer questions when needed) }\end{array}$ & $2(11.8)$ & {$[41,42]$} \\
\hline 03.4: Program did not send reminders, follow-up or visual aids (eg, pamphlets) & $2(11.8)$ & {$[19,50]$} \\
\hline O4: Lack of access to intervention deters willingness to participate & 4 (23.5) & {$[36,40,48,49]$} \\
\hline O4.I: Transport unavailable (eg, no roads to that area, no access to transport to the venue) & $2(11.8)$ & {$[48,49]$} \\
\hline $\begin{array}{l}\text { O4.2: Long distance (eg, too long a distance or commute makes older adults too tired to } \\
\text { participate) }\end{array}$ & $2(11.8)$ & {$[48,49]$} \\
\hline O4.3: Cost (personal financial cost and time cost) & $2(I I .8)$ & {$[36,48]$} \\
\hline $\begin{array}{l}\text { O4.4: Difficulty in accessing healthcare directions or technical support (eg, older adults cannot } \\
\text { access technical support for virtual reality exercises) }\end{array}$ & I (5.9) & [40] \\
\hline
\end{tabular}

(Continued) 
Table 3 (Continued).

\begin{tabular}{|c|c|c|}
\hline Capability-Related Themes & Frequency $(\%)^{*}$ & Article Citation \\
\hline Motivation-Related Themes & Frequency $(\%)^{*}$ & Article Citation \\
\hline $\begin{array}{l}\text { MI: Lack of motivation to carry out or sustain fall-prevention intervention following hospital } \\
\text { discharge or during hospitalization }\end{array}$ & $8(47.1)$ & {$[36,37,41-44,48,49]$} \\
\hline $\begin{array}{l}\text { MI.I: Lack of motivation to participate because of emotional/mental-related issues (eg, sad or not } \\
\text { in the mood to participate) }\end{array}$ & $2(11.8)$ & {$[43,49]$} \\
\hline $\begin{array}{l}\text { MI.2: Unwilling to participate because of spiritual beliefs conflicting with fall-prevention practice } \\
\text { (eg, practicing Tai-Chi may interfere with spiritual beliefs) }\end{array}$ & I (5.9) & [37] \\
\hline $\begin{array}{l}\text { MI.3: Behavior and attitudes towards fall-prevention hindering participation (eg, overconfident in } \\
\text { their own ability to prevent falls) }\end{array}$ & $6(35.2)$ & {$[36,37,41,42,44,48]$} \\
\hline MI.4: Older adults lacking confidence to prevent falls & $2(11.8)$ & {$[48,49]$} \\
\hline M2: Self-denial of being at risk for falls & $2(11.8)$ & {$[36,50]$} \\
\hline M3: Difficulty transitioning between activities of daily living and fall-prevention interventions & I (5.9) & [36] \\
\hline M4: Enthusiasm fatigue & I (5.9) & [37] \\
\hline
\end{tabular}

Notes: *The frequency is the number of cited articles per category. The percentage is the percent out of the 17 articles included in the review. Bold font denotes a main theme.

older adults. $^{34}$ Regarding capability factors, physical health $^{37,42,46}$ and general health issues ${ }^{36,40,47,49}$ were the major capability-related barriers limiting participation in fall-prevention interventions. Use of language and communication aides was found to be the most helpful. $^{36,41,43,46,49}$

Opportunity factors in the COM-B framework included extrinsic or environmental factors among older adults that enabled or prompted their participation. ${ }^{34}$ Lack of institutional support for fallprevention programs was the key opportunity-related barrier. $^{37,38,40-43,46,49}$ Several studies ${ }^{37,38,40,42,49}$ found that health staff often lacked a good understanding of fall-prevention programs ${ }^{37,40,42}$ or were disinterested in promoting fall-prevention interventions due to heavy clinical workloads. ${ }^{37,38,52}$ In contrast, the top three opportunity-related facilitators were institutional and organizational support in assisting fall-prevention programs, ${ }^{36,37,40-43,49,50}$ encouragement and social support for older adults, 5,36,37,41,44,46,48,49 and engaging older adults to mitigate barriers to participating in fallprevention solutions. $5,36,41,48$

Motivational factors in the COM-B framework involved the reflexive and impulsive processes that guide conscious decision-making. ${ }^{34}$ These included a lack of inner drive to carry out or continue involvement in fall-prevention interventions after hospital discharge or during hospitalization, ${ }^{36,37,41-44,48,49}$ self-denial of being at risk for falls, ${ }^{36,50}$ having difficulty transitioning between daily living activities and fall-prevention strategies, ${ }^{36}$ and enthusiasm fatigue. $^{37}$

The three main motivation-related facilitators were following up with older adults, ${ }^{49,50}$ identifying and correcting inaccurate perceptions of falls and fall-prevention strategies, ${ }^{36-38,46,50}$ such as the need for $^{38}$ and benefits of these programs, ${ }^{36,37,46,50}$ and ensuring that older adults realize the personal gain, benefits, and improvements in gait and balance. ${ }^{36}$

In summary, we examined barriers and facilitators to fall-prevention compliance among older adults and how these barriers and facilitator guide behavioral changes following discharge from acute care. Using the innovative approach of the COM-B model of health behavior change $^{34,35}$ to guide this thematic analysis elicited essential insights. The most frequently mentioned barriers and facilitators in each COM-B dimension differed greatly (Tables 3 and 4). The identified gaps could shed light on future fall-prevention intervention designs focusing on behavioral changes in older adults.

\section{Practical Implications}

This scoping review provided a practical understanding of fall prevention relative to behavioral changes and revealed gaps and future research areas in fall prevention. The findings may help guide researchers when co-developing and co-evaluating fall-prevention interventions "with" older adults "for" older adults to avoid preventable falls and fall-related injuries after transitioning home from 
Table 4 Facilitators to Older Adults Participating in Fall-Prevention Strategies After Transitioning Home from Hospitalization ( $\mathrm{n}=17$ Articles)

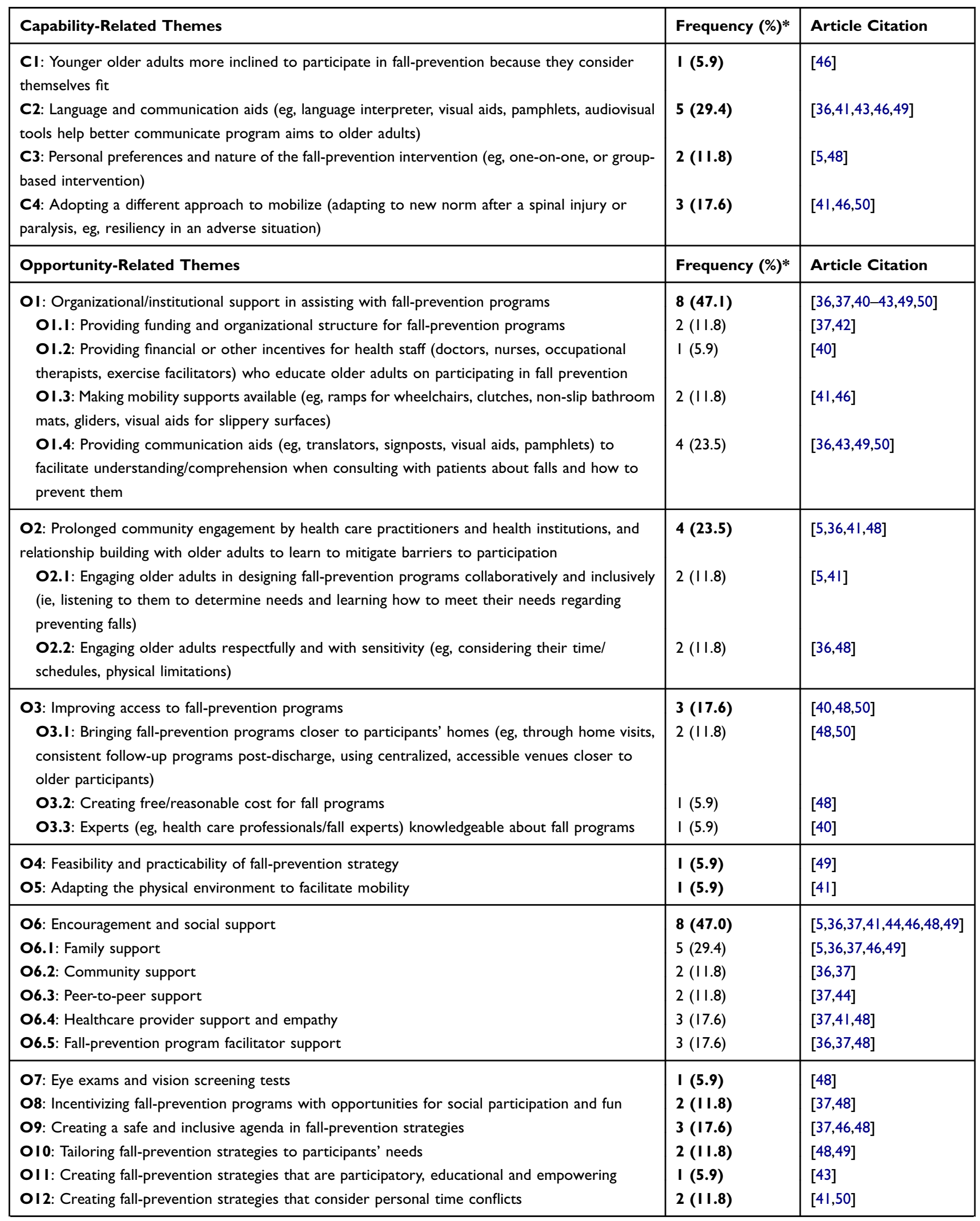

(Continued) 
Table 4 (Continued).

\begin{tabular}{|c|c|c|}
\hline Capability-Related Themes & Frequency $(\%)^{*}$ & Article Citation \\
\hline Motivation-Related Themes & Frequency $(\%)^{*}$ & Article Citation \\
\hline $\begin{array}{l}\text { MI: Following up with older adults (eg, by phone, e-mail or mail) to clarify their understanding of } \\
\text { the fall-prevention program via pamphlets or communicated during hospitalization }\end{array}$ & $2(11.8)$ & {$[49,50]$} \\
\hline M2: Changing inaccurate perceptions of falls and fall-prevention programs & $5(29.4)$ & {$[36-38,46,50]$} \\
\hline M2.I: Perception of need for fall-prevention program & I (5.9) & [38] \\
\hline M2.2: Perception of benefits of a fall-prevention program & $4(23.5)$ & {$[36,37,46,50]$} \\
\hline M3: Seeing personal gain, benefits, and improvements in gait and balance & I (5.9) & [36] \\
\hline
\end{tabular}

Notes: *The frequency is the number of cited articles per category. The percentage is the percent out of the 17 articles included in the review. Bold font denotes a main theme.

acute hospitalization. Two studies ${ }^{5,41}$ suggested engaging older adults in co-designing fall-prevention interventions as a strategy to develop sustainable programs that older adults can easily adopt.

\section{Study Limitations}

We identified two study limitations. First, the varied periods of care transition in each study (eg, from post-hospital discharge up to 8 days to up to 12 months) and the diverse locations for patient recruitment (eg, during hospitalization or from the community) may have contributed to selection bias of the reviewed articles. For example, two reviewed studies $^{36,37}$ addressed fall prevention across the care continuum. Second, appraisal of the risk of bias indicated potential bias in the measurement approaches. Methodological limitations of some included studies could have affected the evidence.

Additionally, this study took an innovative approach to follow the COM-B model of health behavior change as a framework to identify the barrier and facilitator themes; by using this framework, we hope to facilitate future systematic development of falls prevention interventions. The Behavior Change Wheel program planning model provides guidance for matching intervention components to specific theoretical components of the COM-B model. Future research may build on the findings of this scoping review to rigorously and systematically develop patient-centered fall-prevention strategies for behavioral change and hospitals' fall-prevention policies. For example, clinicians in the hospital settings and health researchers could use the results of this review to help them refine hospital policies related to fall prevention to facilitate transition home after an acute hospitalization (eg, increasing mobility).

\section{Conclusion}

This scoping review used the COM-B model of health behavior change ${ }^{34,35}$ as a framework to identify barriers and facilitators to older adults participating in activities to prevent falls after transitioning home from acute hospitalization. The critical barriers and key facilitators in each COM-B dimension differed greatly. The findings of this review may help tailor feasible fall-prevention interventions for older adults after transitioning home from acute hospitalization.

\section{Funding}

Not applicable.

\section{Disclosure}

The authors have no conflicts of interest to declare.

\section{References}

1. Centre for Medicare and Medicaid Services. Medicare and Medicaid Programs; Revisions to Requirements for Discharge Planning for Hospitals, Critical Access Hospitals, and Home Health Agencies, and Hospital and Critical Access Hospital Changes to Promote Innovation, Flexibility, and Improvement in Patient Care. The Daily Journal of the United States Government; 2019. National Archives, a rule by the CMS on published September 30, 2019:51836-51884. Available from: https://www.govinfo.gov/content/pkg/FR-2019-09-30/pdf/201920732.pdf. Accessed May 23, 2020.

2. Hoffman GJ, Liu H, Alexander NB, Tinetti M, Braun TM, Min LC. Posthospital fall injuries and 30-day readmissions in adults 65 years and older. JAMA Netw Open. 2019;2(5):e194276. doi:10.1001/ jamanetworkopen.2019.4276

3. Center for Disease Control and Prevention. Fall data: cost of older adult falls; September 19, 2019. Available from: https://www.cdc.gov/ HomeandRecreationalSafety/Falls/fallcost.html. Accessed May 23, 2020.

4. Milat AJ, Watson WL, Monger C, Barr M, Giffin M, Reid M. Prevalence, circumstances and consequences of falls among community-dwelling older people: results of the 2009 NSW falls prevention baseline survey. NSW Public Health Bull. 2011;22(3-4):43-48. doi:10.1071/NB10065 
5. Hill AM, Etherton-Beer C, Haines TP. Tailored education for older patients to facilitate engagement in falls prevention strategies after hospital discharge-a pilot randomized controlled trial. PLoS One. 2013;8(5):e63450. doi:10.1371/journal.pone.0063450

6. Administration for Community Living. 2018 Profile of Older Americans. U.S. Department of Health and Human Services, Administration for Community Living; 2018. Available from: https://acl.gov/sites/default/files/Aging\%20and\%20Disability\%20in $\% 20$ America/2018OlderAmericansProfile.pdf. Accessed May 23, 2020.

7. Schwendimann R, Buhler H, De Geest S, Milisen K. Falls and consequent injuries in hospitalized patients: effects of an interdisciplinary falls prevention program. BMC Health Serv Res. 2006;6 (1):69. doi:10.1186/1472-6963-6-69

8. National Center for Chronic Disease Prevention and Health Promotion. The state of aging and health in America 2013; 2013. Available from: https://www.cdc.gov/aging/pdf/State-Aging-Healthin-America-2013.pdf. Accessed May 23, 2020.

9. Duckworth M, Adelman J, Belategui K, et al. Assessing the effectiveness of engaging patients and their families in the three-step fall prevention process across modalities of an evidence-based fall prevention toolkit: an implementation science study. $J$ Med Internet Res. 2019;21(1):e10008. doi:10.2196/10008

10. Dykes PC, Duckworth M, Cunningham S, et al. Pilot testing fall tIPS (Tailoring interventions for patient safety): a patient-centered fall prevention toolkit. Jt Comm J Qual Patient Saf. 2017;43(8):403413. doi:10.1016/j.jcjq.2017.05.002

11. McDonald KM, Bryce CL, Graber ML. The patient is in: patient involvement strategies for diagnostic error mitigation. $B M J$ Qual Saf. 2013;22 Suppl 2:ii33-ii39. doi:10.1136/bmjqs-2012001623

12. Morgan L, Flynn L, Robertson E, New S, Forde-Johnston C, McCulloch P. Intentional Rounding: a staff-led quality improvement intervention in the prevention of patient falls. J Clin Nurs. 2017;26 (1-2):115-124. doi:10.1111/jocn.13401

13. Opsahl AG, Ebright P, Cangany M, Lowder M, Scott D, Shaner T. Outcomes of adding patient and family engagement education to fall prevention bundled interventions. J Nurs Care Qual. 2017;32 (3):252-258. doi:10.1097/NCQ.0000000000000232

14. Reuben DB, Gazarian P, Alexander N, et al. The strategies to reduce injuries and develop confidence in elders intervention: falls risk factor assessment and management, patient engagement, and nurse co-management. J Am Geriatr Soc. 2017;65(12):2733-2739. doi:10.1111/jgs. 15121

15. Schnock KO, Howard EP, Dykes PC. Fall prevention self-management among older adults: a systematic review. Am J Prev Med. 2019;56(5):747-755. doi:10.1016/j.amepre.2018.11.007

16. Schnock KO, Snyder JE, Fuller TE, et al. Acute care patient portal intervention: portal use and patient activation. J Med Internet Res. 2019;21(7):e13336. doi:10.2196/13336

17. Hill AM, Etherton-Beer C, McPhail SM, et al. Reducing falls after hospital discharge: a protocol for a randomised controlled trial evaluating an individualised multimodal falls education programme for older adults. BMJ Open. 2017;7(2):e013931. doi:10.1136/bmjopen2016-013931

18. Naseri C, McPhail SM, Haines TP, et al. Evaluation of tailored falls education on older adults' behavior following hospitalization. $J \mathrm{Am}$ Geriatr Soc. 2019;67(11):2274-2281. doi:10.1111/jgs.16053

19. Naseri C, Haines TP, Etherton-Beer C, et al. Reducing falls in older adults recently discharged from hospital: a systematic review and meta-analysis. Age Ageing. 2018;47(4):512-519. doi:10.1093/ageing/afy043

20. Ang E, Mordiffi SZ, Wong HB. Evaluating the use of a targeted multiple intervention strategy in reducing patient falls in an acute care hospital: a randomized controlled trial. J Adv Nurs. 2011;67 (9):1984-1992. doi:10.1111/j.1365-2648.2011.05646.x
21. Avanecean D, Calliste D, Contreras T, Lim Y, Fitzpatrick A. Effectiveness of patient-centered interventions on falls in the acute care setting compared to usual care: a systematic review. JBI Database System Rev Implement Rep. 2017;15(12):3006-3048. doi:10.11124/JBISRIR-2016-003331

22. Dykes PC, Carroll DL, Hurley A, et al. Fall prevention in acute care hospitals: a randomized trial. JAMA. 2010;304(17):1912-1918. doi:10.1001/jama.2010.1567

23. Healey F, Monro A, Cockram A, Adams V, Heseltine D. Using targeted risk factor reduction to prevent falls in older in-patients: a randomised controlled trial. Age Ageing. 2004;33(4):390-395. doi:10.1093/ageing/afh130

24. Yardley L, Donovan-Hall M, Francis K, Todd C. Attitudes and beliefs that predict older people's intention to undertake strength and balance training. J Gerontol B Psychol Sci Soc Sci. 2007;62(2):P119-P125. doi:10.1093/geronb/62.2.p119

25. Grossman DC, Curry SJ, Owens DK, et al.; US Preventive Services Task Force. Interventions to Prevent Falls in Community-Dwelling Older Adults: US Preventive Services Task Force Recommendation Statement. JAMA. 2018;319(16):1696-1704. doi:10.1001/jama.2018. 3097.

26. The American Geriatrics Society. AGS comments to senate special committee on aging on falls prevention; July 2, 2019. Available from: https://www.americangeriatrics.org/sites/default/files/inline-files/AGS $\% 20$ Comments $\% 20$ Senate $\% 20$ Aging $\% 20$ Request $\% 20$ on $\% 20 \mathrm{Falls} \%$ 20Prevention $\% 20 \% 287 \% 202 \% 2019 \% 29 \% 20$ FINAL_1.pdf.

Accessed May 23, 2020.

27. Maar MA, Yeates K, Perkins N, et al. A framework for the study of complex mhealth interventions in diverse cultural settings. JMIR Mhealth Uhealth. 2017;5(4):e47. doi:10.2196/mhealth.7044

28. Peters MD, Godfrey CM, Khalil H, McInerney P, Parker D, Soares CB. Guidance for conducting systematic scoping reviews. Int J Evid Based Healthc. 2015;13(3):141-146. doi:10.1097/XEB.000000000 0000050

29. Arksey H, O’Malley L. Scoping studies: towards a methodological framework. Int J Soc Res Methodol. 2005;8(1):19-32. doi:10.1080/ 1364557032000119616

30. Tricco AC, Lillie E, Zarin W, et al. PRISMA extension for scoping reviews (PRISMA-ScR): checklist and explanation. Ann Intern Med. 2018;169(7):467-473. doi:10.7326/M18-0850

31. Endnote X9.2 MacOS Commercial Software [Computer Program]. Thomson Reuters Corporation; 2019.

32. Microsoft Excel Version 16.32 [Computer Program]. Microsoft Corporation; 2016.

33. Joanna Briggs Institute. Joanna Briggs Institute critical appraisal tools. Adelaide, SA; 2014. Available from: https://joannabriggs.org/ ebp/critical_appraisal_tools. Accessed May 23, 2020.

34. Michie S, van SMM, West R. The behaviour change wheel: a new method for characterising and designing behaviour change interventions. Implement Sci. 2011;6(1):42. doi:10.1186/1748-5908-6-42

35. Michie SA, Atkins L, West R. The Behaviour Change Wheel: A Guide to Designing Interventions: The COM-B Self-Evaluation Questionnaire Can Be Found Pp. 68-69.[Permission granted by Dr. Michie to use this questionnaire]. Great Britain: Silverback Publishing; 2014.

36. Finnegan S, Bruce J, Seers K. What enables older people to continue with their falls prevention exercises? A qualitative systematic review. BMJ Open. 2019;9(4):e026074. doi:10.1136/bmjopen-2018-026074

37. Sandlund M, Skelton DA, Pohl P, Ahlgren C, Melander-Wikman A, Lundin-Olsson L. Gender perspectives on views and preferences of older people on exercise to prevent falls: a systematic mixed studies review. BMC Geriatr. 2017;17(1):58. doi:10.1186/ s12877-017-0451-2

38. Calhoun R, Meischke H, Hammerback K, et al. Older adults' perceptions of clinical fall prevention programs: a qualitative study. $J$ Aging Res. 2011;2011:867341. doi:10.4061/2011/867341 
39. Davenport RD, Vaidean GD, Jones CB, et al. Falls following discharge after an in-hospital fall. BMC Geriatr. 2009;9:53. doi:10.1186/ 1471-2318-9-53

40. Dickinson A, Horton K, Machen I, et al. The role of health professionals in promoting the uptake of fall prevention interventions: a qualitative study of older people's views. Age Ageing. 2011;40 (6):724-730. doi:10.1093/ageing/afr111

41. Hill AM, Hoffmann T, Beer C, et al. Falls after discharge from hospital: is there a gap between older peoples' knowledge about falls prevention strategies and the research evidence? Gerontologist. 2011;51(5):653-662. doi:10.1093/geront/gnr052

42. Hill AM, Hoffmann T, McPhail S, et al. Factors associated with older patients' engagement in exercise after hospital discharge. Arch Phys Med Rehabil. 2011;92(9):1395-1403. doi:10.1016/j. apmr.2011.04.009

43. Lee DCA, Pritchard E, McDermott F, Haines TP. Falls prevention education for older adults during and after hospitalization: A systematic review and meta-analysis. Health Educ J. 2013;73(5):530544. doi:10.1177/0017896913499266

44. McMillan L, Booth J, Currie K, Howe T. 'Balancing risk' after fallinduced hip fracture: the older person's need for information. Int $J$ Older People Nurs. 2014;9(4):249-257. doi:10.1111/opn.12028

45. Vogler CM, Sherrington C, Ogle SJ, Lord SR. Reducing risk of falling in older people discharged from hospital: a randomized controlled trial comparing seated exercises, weight-bearing exercises, and social visits. Arch Phys Med Rehabil. 2009;90(8):1317-1324. doi:10.1016/j.apmr.2009.01.030
46. Wong EL, Woo J, Cheung AW, Yeung PY. Determinants of participation in a fall assessment and prevention programme among elderly fallers in Hong Kong: prospective cohort study. $J$ Adv Nurs. 2011;67 (4):763-773. doi:10.1111/j.1365-2648.2010.05535.x

47. Agmon M, Zisberg A, Tonkikh O, Sinoff G, Shadmi E. Anxiety symptoms during hospitalization of elderly are associated with increased risk of post-discharge falls. Int Psychogeriatr. 2016;28 (6):951-958. doi:10.1017/S1041610215002306

48. Kiami SR, Sky R, Goodgold S. Facilitators and barriers to enrolling in falls prevention programming among community dwelling older adults. Arch Gerontol Geriatr. 2019;82:106-113. doi:10.1016/j.archger.2019.01.006

49. Shuman C, Liu J, Montie M, et al. Patient perceptions and experiences with falls during hospitalization and after discharge. Appl Nurs Res. 2016;31:79-85. doi:10.1016/j.apnr.2016.01.009

50. Shuman CJ, Montie M, Hoffman GJ, et al. Older adults' perceptions of their fall risk and prevention strategies after transitioning from hospital to home. J Gerontol Nurs. 2019;45(1):23-30. doi:10.3928/ 00989134-20190102-04

51. Agency for Healthcare Research and Quality. Preventing falls in hospitals: A toolkit for improving quality of care. Rockville, MD: Agency for Healthcare Research and Quality. AHRQ publication No. 13-0015-EF; January 2013. Available from: https://www.ahrq.gov/professionals/sys tems/hospital/fallpxtoolkit/index.html. Accessed May 23, 2020.

52. Shipman KE, Stammers J, Doyle A, Gittoes N. Delivering a qualityassured fracture liaison service in a UK teaching hospital-is it achievable? Osteoporos Int. 2016;27(10):3049-3056. doi:10.1007/ s00198-016-3639-y
Clinical Interventions in Aging

\section{Publish your work in this journal}

Clinical Interventions in Aging is an international, peer-reviewed journal focusing on evidence-based reports on the value or lack thereof of treatments intended to prevent or delay the onset of maladaptive correlates of aging in human beings. This journal is indexed on PubMed Central, MedLine, CAS, Scopus and the Elsevier

\section{Dovepress}

Bibliographic databases. The manuscript management system is completely online and includes a very quick and fair peer-review system, which is all easy to use. Visit http://www.dovepress.com/ testimonials.php to read real quotes from published authors. 